\title{
ANALISIS PENDAPATAN USAHATANI BUNGA POTONG (Studi Kasus Petani Bunga Krisan Putih di Kelurahan Kakaskasen Dua Kecamatan Tomohon Utara Kota Tomohon)
}

\author{
L. Pangemanan \\ G. Kapantow \\ M. Watung
}

\begin{abstract}
The study entitled "Income Analysis of Cut Flowers Farming (case study of White Chrysanthemum flower farmers at village of Kakaskasen Two, disctrict of North Tomohon)" was conducted to determine how much farmers' income from White Chrysanthemum flower farming in village of Kakaskasen Two, disctrict of North Tomohon and is expected to provide information to farmers about the number of farmers' income from White Chrysanthemum flower farming .

The study lasted from October 2010 until December 2010 starting from data collecting up to preparation of the report. Areas of research conducted in the village of Kakaskasen Two, district of North Tomohon. The retrieved data are primary and secondary data. Primary data were obtained from 20 respondents of White Chrysanthemum flower farmers, which is taken directly appoint (purposive sampling) and secondary data obtained from the office of village of Kakaskasen Two. Income is calculated using the revenue analysis. This analysis can also determine the level of farming efficiency which is calculated by dividing the revenues and costs.

Advantage of White Chrysanthemum flower farming compared to other farming is the use of land that is not too large, on a narrow land, White Chrysanthemums flower can be developed. Other advantages compared to other cut flowers is that White Chrysanthemum flower resistant to dust volcanic Mount Lokon.

Chrysanthemum cultivation activities in the village of Kakaskasen Two is the main income source for farmers to meet the needs of family farmers. This research shows that farmers' income derived from farming of White Chrysanthemum flower is Rp11,132,146 by the efficiency is 4.43. In other words, farming of White Chrysanthemum flower is profitable for farmers.
\end{abstract}

Keywords: Farming, Cut Flower Farming, White Chrysanthemum flower

\section{PENDAHULUAN}

\section{Latar Belakang}

Indonesia merupakan negara tropis,karena terletak digaris khatulistiwa serta memegang peranan penting dari keseluruhan perekonomian nasional. Hal ini dapat ditunjukan dari banyaknya penduduk yang hidup dan bekerja pada sector pertanian atau produk nasional yang berasal dari pertanian $(\mathrm{Mu}-$ byarto, 1995).

Dalam pengolahan usahatani, petani mengupayakan agar hal yang diperoleh secara ekonomis menguntungkan, dimana biaya yang di keluarkan dapat menghasilkan produksi maksimal. Sehingga pada akhirnya pendapatan petani akan meningkat, dan dengan meningkatnya pendapatan maka secara otomatis tingkat kesejahteraan petani tersebut akan meningkat. Sektor pertanian memegang peranan penting dalam kehidupan bangsa Indonesia karena sector pertanian mampu menyediakan lapangan kerja, menyediakan pangan dan dapat menyumbangkan devisa kepada negara. Oleh karena itu, kebijaksanaan pertumbuhan ekonomi yang cukup tinggi dalam penyerapan tenaga kerja dan penanggulangan terpusat pada peningkatatn produksi pertanian. 
Bunga potong merupakan salah satu kegiatan pertanian yang diusahakan petani dalam sektor pertanian. Usaha- usaha produksi bunga potong sekarang ini masih kurang mendapat perhatian dari berbagai pihak, mengingat konsumen bunga potong masih terbatas. Dikarenakan sifat bunga potong yang mudah rusak dan tidak dapat bertahan lama dapat mengurangi nilai ekonomis bunga tersebut.Salah satu komoditi pertanian yang dapat membantu meningkatkan pendapatan dan kesejahteraan petani adalah bunga potong (florikultura). Bunga potong adalah jenis tanaman hias serta bisa digunakan sebagai obat. Bunga potong (florikultura) memiliki beberapa jenis antara lain: gladiol, kerkrily, hebras, aster, krisan, mawar, dan anyelir. Semua jenis bunga potong tersebut mendatangkan nilai ekonomis yang tinggi bagi petani bunga potong.

Bunga Krisan yang mempunyai nama latin Chrysanthenum merupakan salah satu tanaman hias yang mempunyai prospek yang baik untuk dibudidayakan dan dijadikan sumber penghasilan, karena tidak memerlukan lahan yang terlalu besar karena dengan melihat kondisi di daerah penelitian, lahan yang digunakan sebagian petani hanya menggunakan halaman rumah atau pekarangan rumah. Di bandingkan dengan usahatani lainnya yang memerlukan lahan yang besar. Ini di karenakan jarak tanam bunga krisa hanya 5 x $5 \mathrm{~cm}$, sehingga tidak perlu menggunakan lahan yang luas untuk berusahatani.

Bunga krisan juga mempunyai keunggulan yang lebih daripada bunga potong jenis lainnya seperti gladiol, kerkrily, hebras, aster, mawar, dan anyelir. Mengapa di katakan unggul, ini dikarenakan bunga krisan yang mempunyai nama latin Chrysanthenum, tahan akan debu vulkanik gunung berapi.

Produksi bunga potong (Bunga Krisan) di Kota Tomohon kelurahan kakaskasen merupakan pemasok utama bunga potong di Sulawesi utara. Hal ini dapat di lihat pada Tabel 1.

Berdasarkan data yang di peroleh dari BPP (Balai Informasi penyuluh Pertanian), di kota Tomohon kecamatan tomohon utara khusunya kelurahan Kakaskasen II, merupakan sentra produksi bunga potong(Bunga Krisan), dengan luas areal dan produksi yang lebih tinggi dari pada kecama- tan-kecamatan lainnya. Produk bunga krisan memiliki peranan yang sangat penting bagipetani yang mengusahakannya di kelurahan Kakaskasen II. Produksi bunga krisan di kelurahan

Tabel 1. Luas areal dan Produksi Bunga Krisan di Kelurahan Kakaskasen II Tahun 2009

\begin{tabular}{|c|c|c|}
\hline Tahun 2009 & $\begin{array}{c}\text { Luas Lahan } \\
\left(\mathrm{m}^{2}\right)\end{array}$ & $\begin{array}{c}\text { Total } \\
\text { Produksi } \\
\text { (tangkai) }\end{array}$ \\
\hline Januari & 0,06 & 6.000 \\
Februari & 0,02 & 2.000 \\
Maret & 0,02 & 2.000 \\
April & 0,02 & 2.000 \\
Mei & 0,07 & 7.000 \\
Juni & 0,22 & 22.000 \\
Juli & 0,13 & 13.000 \\
Agustus & 0,15 & 15.000 \\
September & 0,2 & 20.000 \\
Oktober & 0,1 & 10.000 \\
November & 0,06 & 6.000 \\
Desember & 0,32 & 32.000 \\
\hline
\end{tabular}

\section{Sumber: Badan Penyuluh Pertanian Kota} Tomohon

ini telah di lakukan sejak lama, dan turun temurun, tujuannya adalah sebagai pendapatan utama bagi petani di kelurahan tersebut. Hal dikarenakan tanaman bunga krisan mampu memberikan pendapatan yang relative lebih tinggi dibandingkan dengan pendapatan yang diperoleh dari cabang usahatani yang lainnya, karena harga jual bunga krisan yang diterima petani rata-rata relatif tinggi.

Petani bunga krisan di kelurahan Kakaskasen II sebagian besar menjual bunga krisan ke daerah Manado, Bitung, Tondano serta daerah Tomohon itu sendiri.Walaupun demikian para petani sudah merasa cukup untuk pendapatan yang diterimanya. Namun, perhitungan pendapatan dari usaha ini jarang dilakukan oleh petani sehingga tidak ada informasi yang jelas sampai berapa besar pendapatan yang diperolehnya dari usahatani bunga krisan. Untuk itu penelitian ini perlu untuk dilaksanakan, 
sehingga dapat diketahui dengan pasti pendapatan yang diperoleh petani dari usahatani bunga potong (krisan).

\section{Rumusan Masalah}

Berdasarkan latar belakang yang dikemukakan di atas, maka yang menjadi permasalahan dalam penelitian ini adalah berapa besar pendapatan dari usahatani bunga krisan.

\section{Tujuan dan Manfaat Penelitian}

Penelitian ini bertujuan untuk mengetahui pendapatan petani dari usahatani bunga krisan di Kelurahan Kakaskasen II Kecamatan Tomohon Utara.

Manfaat dari penelitian ini adalah sebagai bahan informasi bagi petani agar dapat mengembangkan usahatani bunga krisan dan penelitian ini diharapkan akan menjadi bahan pertimbangan untuk penelitian selanjutnya.

\section{TINJAUAN PUSTAKA}

\section{Deskripsi Tanaman Bunga potong}

Bunga potong atau florikultura merupakan tanaman khas daerah tropis atau daerah dataran tinggi.Ada beberapa jenis bunga potong yang di produksi dan di pasarkan di Indonesia, antara lain : mawar, anyelir, gladiol, krisan, antherium, aster, hebras, sedap malam, anggrek, lily, alstromeria, dan molucella (Soekartawi, 1996).

Bunga potong pada umumnya dibudidayakan di daerah dataran tinggi yang berudara sejuk tapi dapat di pasarkan di daerah dataran rendah yang berudara panas. Bunga potong memiliki syarat tumbuh yang dipengaruhi oleh:

- Sinar matahari yang memadai,

- Suhu ata temperature udara $17^{\circ} \mathrm{C}-30^{\circ} \mathrm{C}$,

- Curah hujan dan kelembaban udara yang cukup,

- Medium tanah yang ideal (tanah subur, gembur, dan drainase yang baik).

Permintaan bunga potong dalam jumlah dan jenisnya tidak stabil. Pada saat tertentu permintaan bunga potong tinggi untuk jenis tertentu, tetapi pada saat yang lain terjadi penurunan permintaan. Bunga potong itu sendiri merupakan komoditi yang mudah rusak, dan umurnya pendek. Dengan teknologi pascapanen akan membantu memperpanjang umur simpan bunga potong dengan melakukan pemanenan, penanganan, penyimpanan, transportasi, dan pengepakan yang baik. Namun demikian ongkosnya akan meningkat, sehingga harga jualnya pun tinggi dan akan mempengaruhi permintaan konsumen (Soekartawi, 1996).

Pemanenan bunga potong dapat di lakukan pada saat bung potong telah mekar penuh seperti garberra, antherium, dahlia, anyelir, krisan, aster,. Namun ada pula yang dapat dipotong sebelum bunga mekar seperti mawar, lilly, gladiol, dan sedap malam. Saat panen ini akan mempengaruhi keawetan bunga. Pada umumnya bunga yang akan dipotong pada saat mekar penuh, umur simpanannya lebih pendek pada kondisi suhu kamar, kecuali antherium. Untuk bunga yang di panen pada saat belum mekar umumnya relative lebih lama, kecuali bunga mawar.

\section{Deskripsi Bunga Krisan}

Krisan sebenarnya bunga asli dari kawasan Asia Timur, seperti Korea, Jepang dan China Utara tapi saat ini lebih banyak ditanam di negara eropa dan amerika. Krisan di Perancis disebut Chrysanthème, merupakan bunga yang diasosiasikan dengan duka dan kematian. Krisan putih banyak digunakan untuk pemakaman, dan juga di tanggal 1 November pada saat perayaan La Toussaint (All Saints), Krisan warna warni diserbu untuk menghiasi kuburan. Di Indonesia bunga Krisan dipakai untuk bunga di pernikahan.

Tanaman bunga Krisan sangat cocok ditanam pada lahan dengan ketinggian antara 700-1200 di atas permukaan laut (dpl). Untuk daerah yang curah hujannya tinggi, penanaman harus dilakukan di dalam bangunan rumah plastic (greenhouse), karena tanaman bunga krisan tidak tahan terhadap curah hujan yang terlalu tinggi . Untuk perkembangannya bunga ini butuh cahaya yang lebih lama, untuk itu perlu bantuan cahaya dari lampu TL dan lampu pijar. Penyinaran paling baik di tengah malam antara jam 22.30-01.00 dengan lampu 150 watt untuk areal 9 meter persegi, dan lampu dipasang setinggi 1,5 meter dari permukaan tanah. Periode pemasangan lampu dilakukan sampai fase vegetatif (2-8 minggu) untuk mendorong pemben- 
tukan bunga. Di daerah Kota Tomohon bunga Krisan di tanam di tempat yang terbuka dan sebagian di tanam di dalam greenhouse.

\section{Manfaat Krisan bagi kesehatan}

Krisan jenis Chrysanthemum morifolium or Chrysanthemum indicum, yang warna putih atau kuning bisa dijadikan teh krisan atau Chrysanthemum Tea. Khasiatnya untuk menyembuhkan influenza, jerawat dan mengobati panas dalam dan sakit tenggorokan. Bisa juga digunakan untuk obat demam, mata panas dan berair, pusing-pusing serta untuk membersihkan liver.

\section{Definisi Produksi}

Produksi sering diartikan sebagai penciptaan guna, dimana guna berarti kemampuan barang atau jasa untuk memenuhi kebutuhan manusia. Menurut definisi ini produksi mencangkup pengertian yang luas. Produksi meliputi semua aktifitas dan tidak hanya mencakup pembuatan barang-barang yang dapat dilihat.

Produksi adalah suatu kegiatan untuk meningkatkan manfaat dengan cara mengkombinasikan faktor-faktor produksi kapital, tenaga kerja, teknologi, managerial skill. Produksi merupan usaha meningkatkan manfaat dengan cara mengubah bentuk, memindahkan tempat, dan menyimpan (Soeharno, 2006).

Teori produksi terdiri dari dari beberapa analisa mengenai bagaimana seharusnya pengusaha (wiraswastawan) dalam tingkat teknologi tertentu mengkombinasikan berbagai macam faktor produksi untuk menghasilkan sejumlah produk tertentu seefisien mungkin.

Menurut Agung (1994), produksi adalah hasilhasil dari suatu proses atau aktifitas ekonomi dengan memanfaatkan beberapa masukan atau input. Soekartawi (1995), mengatakan bahwa hasil akhir dari suatu proses berupa produk atau output dapat bervariasi disebabkan karena perpedaan kualitas dan kuantitas dari input faktor yang digunakan.

\section{Konsep Usahatani}

Menurut Soekartawi (1995), usahatani adalah ilmu yang mempelajari bagaimana seseorang mengalokasikan sumberdaya yang ada secara efektif dan efisien dengan tujuan untuk memperoleh keuntungan yang tinggi pada waktu tertentu.Dikatakan efektif bila petani atau produsen dapat mengalokasikan sumberdaya yang mereka miliki atau yang dikuasai sebaik-baiknya dan dikatakan efisien bila pemanfaatan sumberdaya tersebut menghasilkan keluaran (output) yang melebihi masukan (input).

Ratag (1982), mengatakan bahwa ilmu usahatani merupakan ilmu yang mempelajari caracara menentukan serta mengkoordinasikan penggunaan faktor- faktor produksi seefektif mungkin sehingga produksi pertanian memberikan pendapatan keluarga petani yang lebih baik. Definisi ini terkandung satu tujuan utama yaitu peningkatan pendapatan keluarga petani.

Menurut Hernanto (1993) yang menjadi unsur-unsur pokok usahatani yang dikenal dengan faktor-faktor produksi antara lain:

1. Tanah

Dalam usahatani, unsur tanah memiliki peranan sangat penting. Tanah adalah media tumbuh atau tempat tumbuhnya tanaman.

\section{Tenaga kerja}

Tenaga kerja merupakan faktor yang penting bagi keberhasilan atau produksi. Dalam usahatani ditemukan dua macam tenaga kerja yaitu tenaga kerja dalam keluarga dan tenga kerja luar keluarga. Tenaga kerja dalam keluarga adalah tenaga kerja dalam usahatani tidak dibayar upahnya, sedangkan tenaga kerja luar keluarga adalah tenaga dalam usahatani yang dibayarkan upahnya sehingga dinamakan tenaga upahan.

\section{Modal}

Modal adalah barang atau uang yang bersama faktor produksi lainnya dan tenaga kerja serta pengelolaan menghasilkan barang-barang baru yaitu produksi pertanian

\section{Manajemen atau pengelolaan}

Manajemen usahatani adalah kemampuan petani menentukan, mengkoordinasikan faktor produsi yang dikuasainya sebaik-baiknya dan mampu memberikan hasil sebagaimana yang diharapkan. 


\section{Konsep Pendapatan}

Dalam meningkatkan pendapatan, maka petani harus berusaha meningkatkan hasil - hasil produksiagar memperoleh peningkatan pendapatan dengan memaksimalkan input-input faktor yang mempengaruhi (Soekartawi, 1995). Menurut Harnanto (1993), ada beberapa ukuran pendapatan petani yaitu:

a. Pendapatan kerja petani (operator labor income); diperoleh dengan menghitung semua penerimaan yang berasal dari penjualan yang dikonsumsi keluarga dan kenaikan nilai inventaris. Setelah itu dikurangi dengan semua pengeluaran baik yang tunai maupun yang tidak diperhitungkan.

b. Penghasilan kerja petani (operator farm labor earning); diperoleh dari menambah pendapatan kerja petani ditambah dengan penerimaan tidak tunai.

c. Pendapatan kerja keluarga (family farm labor earning); merupakan hasil balas jasa dari petani dan anggota keluarga.

d. Pendapatan keluarga (family income); yaitu dengan menjumlahkan semua pendapatan petani dan keluarganya dari berbagai sumber.

Pendapatan rumah tangga petani bersumber dari dalam usahatani dan perdapatan dari luar usahatani. Pendapatan dari dalam usahatani meliputi Pendapatan dari tanaman yang diusahakan oleh petani. Sedangkan dari luar usahatani bersumber dari pendapatan selain usahatani yang diusahakan (Bunga Krisan).

Berusahatani sebagai suatu kegiatan untuk memperoleh produksi dilahan pertanian, pada akhirnya akan dinilai dari biaya yang dikeluarkan dan penerimaan yang di peroleh. Selisih keduanya merupakan pendapatan dari kegiatan usahatani.

$$
\mathrm{I}=\mathrm{TR}-\mathrm{TC}
$$

\section{Dimana:}

$$
\begin{array}{ll}
\mathrm{I} & =\text { Pendapatan (Income) } \\
\mathrm{TR} & =\text { Total Revenue (Penerimaan) } \\
\mathrm{TC} & =\text { Total Cost (Total biaya) }
\end{array}
$$

Dalam peningkatan pendapatan, maka petani harus berusaha untuk meningkatkan hasil produksi agar memperoleh peningkatan pendapatan dengan memaksimalkan faktor produksi terutama tenaga kerja yang merupakan salah satu faktor yang sangat mempengaruhi dalam usahatani keluarga.

\section{Konsep Biaya}

Dalam arti luas biaya adalah pengorbanan sumber ekonomi yang di ukur dalam satuan uang yang telah terjadi atau kemungkinan akan terjadi untuk mencapai tujuan tertentu (Mulyadi, 1993).

Menurut Harnanto (1993) biaya dalam arti sempit adalah harga pokok (merupakan harga pertukaran dari sumber ekonomi yang dikorbankan atau diserahkan untuk mendapatkan suatu barang dan jasa) dan beban (merupakan pengorbanan yang diperlukan dalam rangka merealisasikan pendapatan).

Menurut Sudarsono (1998), biaya dalam pengertian ekonomi adalah semua beban yang harus ditanggung untuk menyediakan barang yang siap dipakai konsumen. Ada empat unsure pokok dalam definisi biaya yaitu:

1. Biaya merupakan pengorbanan sumber ekonomi

2. Diukur dalam satuan uang

3. Yang telah terjadi atau secara potensial akan terjadi

4. Pengorbanan tersebut untuk tujuan tertentu.

Soekertawi (1995), mengemukakan bahwa biaya usahatani dapat di klasifikasikan menjadi dua yaitu:

1. Biaya tetap (Fixed Cost)

Biaya yang relative tetap jumlahnya dan harus dikeluarkan walaupun produk yang dihasilkan banyak atau sedikit.

2. Biaya tidak tetap (Variable cost)

Biaya tidak tetap yang sifatnya berubahubah tergantung dari besar kecilnya produksi yang dihasilkan.

Biaya sebagai suatu nilai tukar, pengeluaran atau pengorbanan yang dilakukan untuk menjamin perolehan manfaat (Carter William, 2009). Biaya dalam kegiatan usahatani dikeluarkan oleh petani dengan tujuan untuk menghasilkan pendapatan yang tinggi bagi usahatani yang dikerjakan. Dengan mengeluarkan biaya maka pertanian 
mengharapkan pendapatan yang setinggi-tingginya melalui peningkatan produksi.

Biaya sebagai suatu sumberdaya yang dikorbankan atau dilepaskan untuk mencapai tujuan tertentu. Suatu biaya biasanya diukur dalam unit uang yang harus dikeluarkan dalam rangka mendapatkan barang dan jasa (Horngren Charles, Srikant Datar, dan George Foster, 2008).

Biaya merupakan pengeluaran yang terjadi dalam mengorganisir dan melakukan proses produksi. Didalamnya termasuk memplot uang untuk input dan pelayanan yang digunakan dalam produksi. Dalam arti luas, biaya adalah pengorbanan sumber ekonomi yang diukur dalam satuan uang yang telah terjadi atau yang nemungkinan akan terjadi untuk tujuan tertentu.

\section{Konsep Penerimaan}

Penerimaan dapat diartikan sebagai nilai produk total dalam jangka waktu tertentu baik yang dipasarkan maupun tidak (Soekartawi, 2002). Penerimaan juga dapat didefinisikan sebagai nilai uang yang diterima dari penjualan. Penerimaan usahatani yaitu penerimaan dari semua sumber usahatani meliputi nilai jual hasil, penambahan jumlah inventaris, nilai produk yang dikonsumsi petani dan keluarganya. Penerimaan adalah hasil perkalian antara produksi yang diperoleh dengan harga jual produk. Pernyataan ini dapat dituliskan sebagai berikut:

$$
\mathrm{TR}=\mathrm{Y} . \mathrm{Py}
$$

$$
\begin{aligned}
& \text { Dimana: } \\
& \mathrm{TR} \quad=\text { Total Revenue (penerimaan usahatani) } \\
& \mathrm{Y} \quad=\text { Output (produksi yang diperoleh) } \\
& \mathrm{Py} \quad=\text { Price (harga output) }
\end{aligned}
$$

\section{METODOLOGI PENELITIAN}

\section{Metode Pengumpulan Data}

Pengumpulan data dilaksanakan dengan metode survey. Data yang dikumpulkan terdiri dari data primer dan data sekunder. Data primer diperoleh melalui wawancara langsung dengan menggunakan daftar pertanyaan yang telah disiapkan dalam bentuk kuisioner, sedangkan data sekunder diperoleh dari instansi-instansi yang terkait dalam penelitian ini.

\section{Metode Pengambilan Sampel}

Penentuan lokasi penelitian dilakukan secara purposive sampling (tunjuk langsung) dengan pengambilan data secara sample random sampling (acak) yaitu cara pengambilan sampel yang memberikan kesempatan yang sama untuk diambil kepada setiap elemen populasi (petani bunga krisan). Dengan jumlah responden sebanyak 20 orang.

\section{Konsepsi Pengukuran Variabel}

Varibel-variabel yang akan diukur dalam penelitian ini adalah sebagai berikut:

1. Luas lahan yang digunakan petani dalam kegiatan usahatani $\left(\mathrm{m}^{2}\right)$

2. Jumlah produksi yaitu jumlah produksi bunga krisan dalam satu kali panen (tangkai)

3. Harga ( $\mathrm{Rp} /$ tangkai )

Harga yaitu harga jual dari bunga krisan.

4. Biaya produksi (Rp)

Biaya produksi yaitu biaya yang dikeluarkan dalam proses penanaman yang terdiri dari:

a. Biaya tetap Yaitu:

- Biaya penyusutan alat dan bangunan (Rp/tahun),

- Pajak (Rp/tahun).

b. Biaya tidak tetap, yaitu:

- Biaya pupuk (kg),

- Biaya bibit (Rp/bibit)

- Biaya pestisida

- Biaya tenaga kerja (Pengolahan tanah, Persemaian, Penanaman, Pemupukan, Pemeliharaan, Pemberantasan hama dan Panen)

- Biaya transportasi.

5. Penerimaan yaitu total jumlah produksi bunga krisan yang diperoleh per satu kali proses produksi (Rp).

6. Pendapatan usahatani bunga krisan yaitu selisih antara total penerimaan dengan total pengeluaran (Rp).

7. Karateristik petani: umur, tingkat pendidikan dan jumlah tanggungan keluarga. 


\section{Analisis Data}

Analisis data yang digunakan dalam penelitian ini adalah analisis secara deskriptif dan disajikan dalam bentuk tabel. Untuk menganalisis usaha bunga krisan dalam perolehan Pendapatan, Menggunakan rumus:

Dimana:

$$
\mathrm{I}=\mathrm{TR}-\mathrm{TC}
$$

$$
\begin{array}{ll}
\mathrm{I} & =\text { Income (pendapatan) } \\
\mathrm{TR} & =\text { Total Revenue (Total Penerimaan) } \\
\mathrm{TC} & =\text { Total Cost (Total Biaya) }
\end{array}
$$

Total penerimaan dalam usaha bunga krisan diperoleh dari jumlah produksi dikali dengan harga jual bunga tersebut. Sedangkan untuk total biaya dihitung dari biaya-biaya yang dikeluarkan untuk usaha penanaman bunga krisan.

$$
\mathrm{TR}=\mathrm{Y} . \mathrm{Py}
$$

Dimana:

TR = Total Revenue (Penerimaan Usahatani)

$\mathrm{Y}=$ Output (Produksi yang Diperoleh)

Py = Price (Harga Output)

Untuk mengetahui tingkat efisiensi dalam usahatani tanaman bunga krisan, dilanjutkan dengan menghitung Return Cost Ratio (R/C). Menurut Soekartawi (1995), analisis Return Cost Ratio adalah mengetahui tingkat keberhasilan usahatani dilihat dari ukuran perbandingan antara penerimaan(Return) dan biaya (cost) dengan formulasi dibawah ini:

$$
\mathrm{a}=\mathrm{R} / \mathrm{C}
$$

Dimana:

$$
\begin{aligned}
\mathrm{a} & =\text { Perbandingan penerimaan dan biaya } \\
\mathrm{R} & =\text { Return (penerimaan) } \\
\mathrm{C} & =\text { Cost (biaya) }
\end{aligned}
$$

\section{Waktu Dan Tempat Penelitian}

Penelitian dilaksanakan selama tiga bulan yaitu bulan Oktober 2010 sampai dengan bulan Desember 2010, mulai dengan persiapan, pengumpulan data, hingga penyusunan laporan hasil penelitian. Tempat Penelitian dilaksanakan di Kelurahan Kakaskasen II Kecamatan Tomohon Utara.

\section{HASIL PENELITIAN DAN PEMBAHASAN}

\section{Luas Lahan}

Keadaan luas lahan akan mempengaruhi tingkat produksi petani bunga krisan. Untuk usahatani bunga krisan petani biasanya tidak memerlukan lahan yang besar seperti usahatani tanaman pangan. Pada lahan pekarang yang sempit saja tanaman bunga krisan sudah bisa dikembangkan. Luas lahan yang ditanami bunga krisan dapat dilihat pada Tabel 2.

Tabel 2. Jumlah dan Persentase Petani Menurut Luas Lahan

\begin{tabular}{|c|c|c|}
\hline $\begin{array}{c}\text { Luas lahan } \\
\left(\mathrm{m}^{2}\right)\end{array}$ & $\begin{array}{c}\text { Jumlah petani } \\
\text { (orang) }\end{array}$ & $\begin{array}{c}\text { Persentase } \\
(\%)\end{array}$ \\
\hline $10-50$ & 4 & 20 \\
\hline $51-100$ & 4 & 20 \\
\hline $101-150$ & 6 & 30 \\
\hline $151-200$ & 6 & 30 \\
\hline Jumlah & 20 & 100 \\
\hline
\end{tabular}

Sumber: data primer 2010

Dari Tabel 2 diperoleh data bahwa petani responden memilki lahan yang relative kecil berkisar antara $10-50 \mathrm{~m}^{2}$. Usahatani ini dapat dikembangkan pada lahan yang kecil karena jarak tanamnya hanya 5 x $5 \mathrm{~cm}$.

\section{Status Pemilikan Lahan}

Status lahan yang dimiliki petani menentukan besar kecilnya pendapatan yang diterima. Dari hasil penelitian ini menunjukan bahwa lahan usahatani di Kelurahan Kakaskasen Dua pada umumnya milik sendiri.

\section{Produksi}

Produksi adalah proses menggunakan sumber daya untuk menghasilkan barang dan jasa. Kualitas, dan kuantitas produk akan tergantung dari input factor yang digunakan akan menurunkan kualitas, dan kuantitas produksi. Usaha peningkatan produksi sekarang ini bukan lagi semata-mata untuk peningkatan kuantitas hasil panen, tetapi ditujukan kepada peningkatan pendapatan petani. Oleh sebab itu petani sekarang lebih berorientasi terhadap harga. Produksi yang meningkat tanpa didukung oleh tingkat harga yang menguntungkan 
maka tidak akang memberikan jaminan bagi peningkatan pendapatan usahatani.

Tabel 3. Rata-rata Luas Lahan, Rata-Rata Produksi, dan Harga Bunga Krisan

\begin{tabular}{|c|c|c|}
\hline $\begin{array}{c}\text { Luas Lahan } \\
\left(\mathrm{m}^{2}\right)\end{array}$ & Produksi Rata-rata & $\begin{array}{c}\text { Harga } \\
(\mathrm{Rp})\end{array}$ \\
\hline 118 & 5750 & 2500 \\
\hline
\end{tabular}

Sumber: Data primer,2010

Pada Tabel 3, produksi bunga krisan dalam satu kali proses produksi, berdasarkan hasil penelitian luas lahan rata-rata petani bunga krisan adalah $118 \mathrm{~m}^{2}$, dengan rata-rataproduksi dalam satu kali musim panen 5750 tangkai, dengan harga 2.500/tangkai.

\section{Biaya Produksi}

Biaya produksi adalah semua biaya yang dikeluarkan petani untuk produksi selama satu tahun proses produksi. Biaya produksi bunga krisan dapat dilihat pada Tabel 4.

Tabel 4. Rata-rata Biaya Produksi Usahatani Bunga Krisan dalam Satu Kali Musim Panen

\begin{tabular}{|l|c|c|}
\hline \multirow{2}{*}{ Biaya Produksi } & \multicolumn{2}{|c|}{$\begin{array}{c}\text { Usahatani } \\
\text { Bunga Krisan }\end{array}$} \\
\cline { 2 - 3 } & Rp & $\%$ \\
\hline A. Biaya Tetap & 97.850 & 3,01 \\
\hline - Biaya pajak lahan & $540.722,84$ & 16,67 \\
\hline $\begin{array}{l}\text { - Penyusutan alat } \\
\text { dan bangunan }\end{array}$ & \\
\hline Jumlah biaya tetap & $638.572,84$ & 19,68 \\
\hline B. Biaya Variabel & 2320000 & 71,5 \\
\hline - Bibit & 28211,25 & 0,86 \\
\hline - Pupuk & 24889,58 & 0,75 \\
\hline - Pestisida & 243000 & 7,21 \\
\hline - Tenaga Kerja & - & - \\
\hline - Transportasi & 2604280,83 & 80,32 \\
\hline Jumlah biaya variabel & 3242853,74 & 100 \\
\hline Total biaya produksi
\end{tabular}

Sumber: Data Primer 2010

Tabel 4 menunjukan bahwa rata-ratabiaya produksi bunga krisan dalam satu kali proses pro- duksi yang digunakan pada usahatani bunga krisan untuk kel. Kakaskasen dua sebesar Rp3.242.853,74. Biaya variable untuk biaya bibit Rp2.320.000 (71,5 persen). Sehingga dapat dilihat bahwa biaya untuk bibit merupakan biaya terbesar dalam satu kali proses produksi bunga krisan.

\section{Biaya Tetap}

\section{- Pajak lahan}

Biaya pajak lahan di Kelurahan Kakaskasen Dua Kota Tomohon bervariasi tergantung besar luasan lahan yang di miliki oleh petani, berdasarkan penelitian ini rata-ratapajak per tahun Rp97.850

- Penyusutan alat dan bangunan

Untuk biaya penyusutan alat dan bangunan di hitung berdasarkan kepemilikan dari petani responden. Dalam penelitian ini yang akan di hitung adalah cangkul, gunting, parang dan grand house. Rata-ratausia ekonomis $4-5$ tahun, dan rata-ratabiaya penyusutan per tahun Rp540.722,84

Bibit

\section{Biaya Variabel}

Varietas bibit yang di gunakan oleh petani responden adalah krisan/seruni walanda (putih). Harga bibit bunga krisan yang didatangkan dari pulau jawa Rp300 per bibit. Sedangkan biaya kirim bibit dari pulau jawa ditanggung oleh pengirim bibit. Hal ini sangat menguntungkan bagi petani bunga krisan karena petani bunga krisan dapat mengurangi biaya pengiriman bibit. Pada waktu di daerah penelitian adalah harga per bibit Rp400. Dan rata-rata penggunaan bibit dalam satu kali musim tanam adalah Rp2.320.000.

\section{$\underline{\text { Pupuk dan pestisida }}$}

Untuk bunga krisan petani responden menggunakan pupuk berupa pupuk urea, dan phonska rata-rata pembelian pupuk dalam satu kali musim tanam sebesar Rp28.211,25, sedangkan pestisida berupa Decis, Detain dan Antrakol. Rata-rata biaya yang di keluarkan untuk pembelian pestisida dalam satu kali musim tanam sebesar Rp24.889,58. 


\section{Tenaga kerja}

Tenaga kerja yang di pekerjakan mulai dari proses pengolahan sampai pada proses panen secara keseluruhan adalah laki-laki. Biaya tenaga kerja yang berlaku di daerah penelitian per hari sebesar Rp60.000 dengan rata-rata biaya tenaga kerja dalam satu tahun Rp243.000 atau 7,21 persen dari total biaya produksi.

\section{Transportasi}

Petani responden di Kelurahan Kakaskasen Dua tidak mengeluarkan biaya transportasi untuk kegiatan pemasaran hasil panen, karena biasanya konsumen yang datang langsung membeli di lahan milik petani. Hal ini di karenakan jumlah permintaan terhadap bunga krisan yang sangat besar, sehingga konsumen langsung datang ke lahan milik petani untuk membeli bunga.

\section{Penerimaan dan Pendapatan}

Penerimaan adalah perkalian antara produksi yang diperoleh dengan harga jual produk tersebut. Pendapatan usahatani adalah selisih antara penerimaan dan semua biaya yang dikeluarkan dalam suatu usahatani.

Pendapatan dalam pengertian dalam pengertian teknisnya dikatakan sebagai selisih antara penerimaan dengan pengeluaran dalam produksi bunga krisan yang dihitung dalam jangka waktu tertentu. Dalam penelitian ini pendapatan yang akan dihitung adalah pada masa produksi terakhir, hal dapat dilihat pada Tabel 5.

Tabel 5. Pendapatan Petani Bunga Krisan Putih Pada Produksi Terakhir, di Kelurahan Kakaskasen Dua, 2010

\begin{tabular}{|l|c|}
\hline \multicolumn{1}{|c|}{ Uraian } & Rata-rata Per Petani \\
\hline Penerimaan (Rp) & 14.375 .000 \\
\hline Biaya (Rp) & $3.242 .853,74$ \\
\hline Pendapatan (Rp) & $11.132 .146,25$ \\
\hline
\end{tabular}

Sumber: data primer, 2010

Tabel 5 dapat dilihat penerimaan petani dalam produksi terakhir bunga krisan, diperoleh dari hasil perkalian antara (produksi bunga krisan $<$ jumlah tanaman $>\mathrm{x}$ harga jual bunga krisan $<\mathrm{Rp}>$ ) dengan harga jual ditingkat petani di kel.kakaskasen dua sebesar 2500/tangkai. Dengan rata-ratapenerimaan adalah Rp14.375.000 dan rata-ratapendapatan sebesar Rp11.132.146,25 diperoleh dari (penerimaan - total biaya produksi), atau

Pendapatan dalam penelitian ini dapat dilihat pada lampiran 6 menunjukan bahwa total Penerimaan Rata-rata per meter persegi $\left(\mathrm{m}^{2}\right)$ usahatani bunga krisan di Kelurahan Kakaskasen Dua Kecamatan Tomohon Utara yaitu sebesar Rp14.375.000 sedangkan total biaya rata-rata per meter persegi $\left(\mathrm{m}^{2}\right)$ yaitu sebesar Rp3.242.853,74 dan pendapatan yaitu Rp11.132.146,25

\section{Analisis Return Cost Ratio}

Analisis Return Cost Ratio atau analisis Penerimaan dan Biaya produksi terhadap penelitian ini bertujuan untuk mengetahui berapa besar tingkat keberhasilan dari usahatani bunga krisan di kelurahan Kakaskasen dua, Kecamatan Tomohon Utara.

Rata-rata jumlah produksi bunga krisan yang dijual oleh petani adalah 23.200 tangkai, dan ratarata harga jualnya adalah Rp2.500 per tangkai, sehingga rata-ratapenerimaan dari usahatani bunga krisan adalah Rp2.500 x $5.750=$ Rp14.375.000

Total biaya rata-ratayang dikeluarkan dalam satu kali musim proses produksi adalah Rp3.242.853,74. Dengan demikian nilai R/C Usahatani bunga krisan adalah 4,43 yang berarti bahwa setiap Rp1,00 yang digunakan dalam usahatani, akan menghasilkan penerimaan sebesar 4,43.

Dari hasil penelitian diperoleh nilai R/C adalah $>1$, atau dengan kata lain usahatani ini menguntungkan bagi petani bunga krisan di Kelurahan Kakasakasen Dua, Kecamatan Tomohon Utara.

\section{KESIMPULAN DAN SARAN}

\section{Kesimpulan}

Berdasarkan hasil penelitian menunjukkan bahwa usahatani Bunga Krisan di Kelurahan Kakaskasen Dua Kecamatan Tomohon Utara dapat di simpulkan bahwa:

1. Keunggulan usahatani bunga krisan adalah penggunaan lahan yang tidak terlalu besar, serta bunga krisan tahan akan abu vulkanik gunung berapi. 
2. Pendapatan yang di terima oleh petani dalam satu kali proses produksi berusahatani bunga krisan di Kelurahan Kakaskasen Dua Kecamatan Tomohon Utara di sebesar Rp11.132.146,25

3. Kegiatan bercocok tanam bunga krisan di Kelurahan Kakaskasen Dua Kecamatan Tomohon Utara masih menjadi sumber pendapatan utama bagi petani untuk memenuhi kebutuhan keluarga petani.

4. Total biaya rata-ratayang dikeluarkan dalam satu kali musim proses produksi adalah Rp3.242.853,74. Dengan demikian nilai R/C Usahatani bunga krisan adalah 4,43 yang berarti bahwa setiap Rp1,00 yang digunakan dalam usahatani, akan menghasilkan penerimaan sebesar 4,43. Dari hasil penelitian diperoleh nilai $\mathrm{R} / \mathrm{C}$ adalah $>1$, atau dengan kata lain usahatani ini menguntungkan bagi petani bunga krisan di Kelurahan Kakasakasen Dua, Kecamatan Tomohon Utara.

\section{Saran}

1. Perlu adanya peran dari pemerintah atau lembaga yang terkait didalamnya untuk menjaga kestabilan harga produk bunga krisan, sehingga petani bisa mendapatkan harga yang layak.
2. Bagi petani disarankan untuk terus meningkatkan produksi, karena jumlah permintaan yang tinggi. Dan disarankan bagi petani untuk menanam bunga krisan bukan hanya terbatas pada varietas local saja tetapi juga varietas bunga krisan yang berasal dari luar daerah yang lebih banyak dimintai konsumen.

\section{DAFTAR PUSTAKA}

Anonimous, 2010. http://www.ibujempol.com/bunga-krisan/.

Carter William, 2009. Akutansi Biaya - Buku I Edisi 14. Penerbit Salemba. Jakarta.

Downey \& Erickson, 1992. Manajemen Agribisnis, Erlangga, Jakarta.

Hernanto, 1993. Ilmu Usahatani. Departemen Sosial Ekonomi. Bandung.

Horngren Charles, Srikant Datar, dan George Foster, 2008. Biaya Akutansi - Penekanan Managerial Edisi XI Jilid 1. Penerbit PT. Indeks. Jakarta.

Mubyarto, 1995. Pengantar Ekonomi pertania. LP3S. Jakarta. Mulyadi, 1993. Akutansi biaya. STIE YKPN. Yogyakarta.

Ratag, J,. 1982. Dasar - Dasar Pengelolaan Usahatani. Fakultas Pertanian Universitas Sam Ratulangi. Manado. 